\title{
Enhancing Railway Engineering Student Engagement Using Interactive Technology Embedded with Infotainment
}

\author{
Sakdirat Kaewunruen
}

School of Engineering, The University of Birmingham, Birmingham B15 2TT, UK; s.kaewunruen@bham.ac.uk; Tel.: +44-121-414-2670

Received: 30 April 2019; Accepted: 13 June 2019; Published: 16 June 2019

\begin{abstract}
Interactive learning technology is an emerging innovation for future communication-aided teaching and learning that could positively enhance students' engagement and intrinsic motivation. Due to the virtue of interactive communication, classrooms are now anticipated to enable a variety of interaction-based learning technologies with diverse infotainment (a subset of "serious play") integrated with practical enquiry-based projects and case studies for employability improvement. In this paper, a comprehensive review of various teaching and learning pedagogies is assessed. Their suitability and association with infotainment and interactive technology is discussed and highlighted. In addition, a recent research activity on interactive communication is presented to form a new teaching application using interactive technology and infotainment (or edutainment) appropriate for student engagement in railway geometry and alignment design classes. The development of the integrated interactive technology and infotainment was implemented and evaluated in a postgraduate railway engineering class. Questionnaires were used to survey students' experiences in the classes with and without the technology enhanced learning. The outcome clearly shows that students enjoyed and felt they were significantly engaged in the class with the new interactive resources. Their participation and learning performance increased. Despite the favourable outcomes, the flexibility and viability of using this interactive technology still largely depends on the students' background and their previous experience.
\end{abstract}

Keywords: student engagement; interactive technology; active learning; clickers; infotainment; edutainment; teaching approaches; railway engineering

\section{Introduction}

Many British academic institutions are nervous about the outcome of the National Student Survey (NSS). In recent years, many institutions have tried to increase their NSS score by enabling teaching excellence. The NSS outcomes have informed us that students live digitally and they love having digital and interactive technologies embedded in a classroom [1,2]. Some examples are videos (e.g., Panopto, YouTube), infographic social media (e.g., Twitter, Instagram), and other technologies (e.g., Canvas, Blackboard). The uses of interactive technologies have become even more important as more students adopt various technology devices in their lives. These trends prompt the necessity to develop and implement technology enhanced learning, which engage students both inside and outside the classroom. This development indeed responds directly to various elements of the United Kingdom Professional Standards Framework in the Digital Age, such as: A1: design and plan learning activity; A4: develop effective learning environments; K3: how students learn; K4: the use of appropriate learning technologies; and V2: promote participation and equality for learners [3]. The focus of this study is placed on a specialized course for higher education in the United Kingdom. The similarity 
of the concept can vary from one country or continent to another, depending on the culture, norm, and values embedded in their educational systems. However, such aspects are beyond the scope of this study.

A number of diverse information and communication technologies (ICT) have been adopted in higher engineering education sector. By enabling active learning, the common goals are to increase students' intrinsic motivation, promote participation, and enhance learning outcomes [4-7]. Despite the diversity of student backgrounds, levels of study, and class environments, many attempts have led to best practices for facilitating ICTs in combination with flexible and suitable teaching pedagogies in higher education. In order to improve the student learning experience, an array of various teaching pedagogies suitable for a class situation are often used [8-11]. The use of the ICTs can, thus, benefit the adaptive teaching strategies and engage all students with different backgrounds.

Previous case studies in higher education institutions have demonstrated many benefits of interactive technology, such as clickers, student response systems via smart phones or tablets, interactive board, etc. [12-14]. The studies based on only student perceptions (opinion-based survey) found that students enjoy using the interactive technology and become much more engaged. With respect to clickers, Beatty et al. [15], Martyn [16], and Bruff [17] also found that clickers provide an anonymity for students to actively participate in class without fear of public humiliation; the tool creates "fun" and "game-based learning" that engages students more than traditional teaching. The peer game-based instruction could support deep learning [18]. This could be done by developing a class quiz for students to work individually or as a team to compete for the most appropriate, most-efficient, lowest-cost, or lowest-carbon-footprint solutions. Based on a number of similar findings in various cases $[12,19,20]$, the integration of interactive technology and infotainment (a teaching medium both to entertain and to inform) can be complementarily established. The use of entertainment for an interactive teaching pedagogy has been acknowledged worldwide. For example, Jenkin [21] fully supported "fun" in teaching from his statement "play not only aids children's mental and physical health, it teaches them risk taking and problem solving skills, promoting imagination, independence, and creativity." This nature could be applied to higher education learners. In addition, clickers could be used as an alternative tactic to traditional class discussion in order to enhance active learning pedagogy $[16,22,23]$.

Current teaching approaches within higher education uses adaptive blended learning, where students can attain a combination of teaching methods or pedagogies [24]. These adaptive approaches imply common practices in tailored teaching and learning, and have been supported by researches [25-28]. They are recommended to best engage students and to promote personalised technology enhanced learning. In fact, these approaches resonate with the active learning pedagogy, where students are actively engaged to learn through discovering, processing, and applying knowledge [29,30]. The forms of active learning can be cooperative learning or small group teaching [31,32], peer and group discussions [20], simulations and games [33], student response assistance, clickers [16,25], and so on. Despite the pros and cons of each form [34-37], there is an agreement [38-40] that the growth of personal technology integration in classrooms has been paramount and inevitable in higher education. In addition, many educators $[19,41-46]$ have vigorously advocated that active learning through personalised responsive technology is one of the best teaching pedagogies and one of the most suitable practices for digital-native engineering students, especially in the 21st century. Many have also adopted it for a wide range of classes and leaners [47].

Clickers are personal response technology enhanced learning. They actively engage students during the entire class period. The prompt responses from clickers can gauge the level of understanding of the class so that lecturers can provide prompt feedback and enable adaptive teaching styles and blended pedagogies, resulting in a suitable harmonised student-centred learning environment. Martyn [16] supported this technology, stating that "clickers allow students to engage and provide input without fear of public humiliation and without having to worry about more vocal students dominating the discussion". However, she argued whether the clickers could actually help improve student learning outcome. Her study based on small class groups (about 20 students each) showed 
that clickers did not improve the learning outcomes when compared with another active learning pedagogy (using traditional class discussion). In contrast, recent findings based on larger sizes of class (>50 students) suggest otherwise [11,48,49]. They found that clickers consistently produced better learning outcomes as they play a significant role in cognitive learning; and they promote fact retention, even though they may impede conceptual understanding. Also, clickers seem to positively influence the intrinsic motivation and improve grades or final marks of students. These recent findings confirmed that one size does not fit all. Active learning tactics, such as group discussion or collaborative learning, might not be effective for larger class sizes [24]. Thus, personal responsive technology, such as clickers or smart phones, has been a revolutionary and inevitable teaching assistant tool in higher education, especially when looking towards the future. In the present day, smart phones are affordable and have been used in various classes.

Despite the popularity of clickers in university teaching, a critical literature review shows that the use of audience response systems (or clickers) is still limited in engineering fields $[9,10,50,51]$ and is non-existent in railway engineering education. In this study, the learning activity and resources integrated with clickers have been developed. This unprecedented study explores the possible relationships between the interactive technology integrated with infotainment and student engagement in postgraduate railway engineering education. The educational development has been targeted at postgraduate students with different professional and demographic backgrounds. The lecture topic of track geometry and alignment design with over 50 students has been chosen particularly since many previous students had considered it as one of the most difficult topics in railway infrastructure modules. Many students were lacking confidence in applying the knowledge, demotivated, and disengaged from the learning process. The goal of this development is to understand if the clickers can better engage students in the seminar-style lecture, resulting in the enhancement of students' intrinsic motivation through active learning pedagogy. This study highlights the comparison of the student perception-based surveys considering the result in 2016 (using traditional group and class discussions) and its counterpart in 2017 (using clickers and infotainment). The work is aimed at improving the quality of higher education with respect to a railway engineering program by using an interactive technology and "fun" educational content to improve students' engagement, despite a common thought that engineering is a serious profession. The student learning performance based on an oral assessment of a group of final-year students from both cohorts is also evaluated to understand the role of interactive technology on the student learning outcome in a postgraduate railway infrastructure engineering module.

\section{Development of Learning Activity and Resources with Integrated Learning Technology}

The railway infrastructure module is a core module for the postgraduate programs MSc Railway Systems Engineering and Integration and MSc Railway Risk and Safety Management at the University of Birmingham. About 50 students or more enroll in this module every year, forming large-size classes for a masters level module. This module consists of a variety of lecture topics delivered by internal and external guest lecturers. The use of Canvas (digital communication and online learning materials) and Panopto (video records) have already been exploited to foster the digital learning process for students, starting in 2015. However, a constraint that discourages lecturers from utilising Panopto is that proprietary videos and multi-media are often used in class to enhance experiential-based learning pedagogy. A number of videos, simulations, and multi-media belong to the rail industry and private companies. For educational purposes, all classes are, however, recorded via Panopto to aid student learning experience. Reportedly, many students very much enjoy and appreciate using Panopto [1]. For this study, a specific topic has been chosen using the author's teaching responsibility in order to quantify the students' responses and learning outcome. With respect to the topic of track geometry and alignment design, the author has been solely responsible for the class lectures since 2015. Many past and previous students had negative experiences regarding the topic as it has been one of the most difficult lectures. They stated that they were not confident enough to apply the knowledge, were 
demotivated, and disengaged. A large number of students have failed the examination in the past. These issues have inspired the lecturer to adopt an active learning pedagogy to enhance the student experience. In 2016, industry case studies (project- and enquiry-based learning) were used in class for group work and class discussions (see Appendix A), aiming to enhance employability skills, as shown in Table 1. The seminar-style lecture was then developed to enact active learning integrated with the project-based learning approach [52] and multi-media to enhance the experiential learning of the students $[53,54]$.

Table 1. Engineering employability skills required by employers, adopted from Kaewunruen [55].

\begin{tabular}{|c|c|c|}
\hline U.K. [56] & Singapore [57] & Japan [57] \\
\hline $\begin{array}{ll}\text { - } & \text { New and specific technical skills } \\
\text { - } & \text { Computer literacy and IT skills } \\
\text { - } & \text { Multi-skilling and greater -flexibility } \\
\text { - } & \text { The ability to deal with change } \\
\text { An ability to continue } \\
\text { learning, re-skilling } \\
\text { - } \quad \text { Communication skill } \\
\text { Team working and getting on with } \\
\text { others, including being able to work } \\
\text { in self-managed teams } \\
\text { - } \quad \text { problem-solving and diagnosis } \\
\text { "Whole system” thinking }\end{array}$ & $\begin{array}{ll}- & \text { Workplace literacy } \\
- & \text { and numeracy } \\
- & \text { IT and Technology } \\
- & \text { Problem solving } \\
- & \text { Initiative and enterprise } \\
- & \text { Communication } \\
& \text { and Relationship } \\
- & \text { Lifelong learning } \\
- & \text { Globalisation } \\
- & \text { Self-management } \\
- & \text { Workplace-related life skills } \\
- & \text { Health and workplace safety }\end{array}$ & $\begin{array}{ll}- & \text { Communication skills } \\
- & \text { Problem solving } \\
- & \text { Goal-setting skill } \\
- & \text { Personal presentation skills } \\
- & \text { Visioning skills } \\
- & \text { IT and computer } \\
- & \text { Leadership } \\
- & \text { Self-assessment skills }\end{array}$ \\
\hline
\end{tabular}

Interactive technology (using TurningPoint Technology's clickers) embedded with infotainment (game-based questions and fun quizzes) in the class slides (using MS Powerpoint) have, thus, been further developed as a new learning resource since late 2016 (see Appendix B). The development has fully recognised that students have different professional and cultural backgrounds and conceptions of learning; students' expectations and conceptions of learning shape how they approach study tasks and class activities. Several multi-media have been used in class to offer story telling entertainment to enhance the learning experience and create deeper learning. Clickers associated with infotainment-based questions have been developed and used to engage all students (from passive to active learning) and obtain class feedback for adaptive teaching tactics. The use of clickers has been designed to provide a break between key technical concepts to gauge students' understanding of the materials, to engage every student via game approach, as well as short class discussions, and to revive their energy and attention by infotainment. A number of multiple choice questions were set to obtain student responses. The questions were designed to allow students to have peer or group discussions before or after the vote. These discussions are critically important as they enhance the communication skills of individual students. Data received from students were acquired by a dongle plugged into a PC in front of the class. These data were then saved onto the powerpoint for discussion and analyses in this study.

\section{Evaluation Plan}

The effectiveness of interactive teaching and student engagement are evaluated using perception-based questionnaires (see Appendix C). All students in class were given the questionnaires immediately after each lecture to evaluate their fresh perspectives on the teaching styles and their feelings towards the level of engagement. The questionnaire is aimed at echoing the students' feedback about the teaching pedagogy (active learning), the use of digital technology, the advantages and preference of using technology (i.e., Panopto), the preference towards teaching styles, delivery mode, quality of teaching materials, and the use of online communication (i.e., Canvas). These perception-based questions were later correlated with the demographical data of students, including 
gender, English proficiency, cultural background, professional experience, and digital-native orientation. Almost every student (approximately 40-50 students) each year took part in the surveys.

Student learning outcomes are also measured by taking the score from the oral examination of students (based on the curriculum of MSc Railway Risk and Safety Management) at the end of the year 2016/2017 (taken in May 2017) using situation-based enquiries. Out of 11 candidates (the whole cohort), five students (part timers) took the class in 2016 (traditional class discussion) and the rest were in 2017 lecture (interactive technology). This was the only formal evaluation available to critically evaluate "student learning", as all exams are normally conducted at the end of the program (e.g., end of academic year). The students were given the case scenario an hour prior to the oral exam. In the exam, the students had $10 \mathrm{~min}$ to read exam questions and prepare answers. Then, they were interviewed using the given questions and evaluated from the completeness of answers and application of knowledge to the case scenario. Two experienced assessors marked each student independently to assure fairness and comprehensiveness. The whole interview examination takes $30 \mathrm{~min}$ for each candidate.

\section{Learning Design Flow Map}

The new lecture developed in 2017 has embedded interactive technology and infotainment to activate students' active learning and deeper thinking. The use of clickers is found to be very appropriate for this lecture ( $>50$ students), since Hoekstra and Mollborn [58] also found that seminar-style discussions or lectures become more difficult when the class contains more than 35 students. Based on a teaching conceptual analysis in accordance with Blasco-Arcas et al. [7], Figure 1 shows the learning concept framework of the interactive lecture.

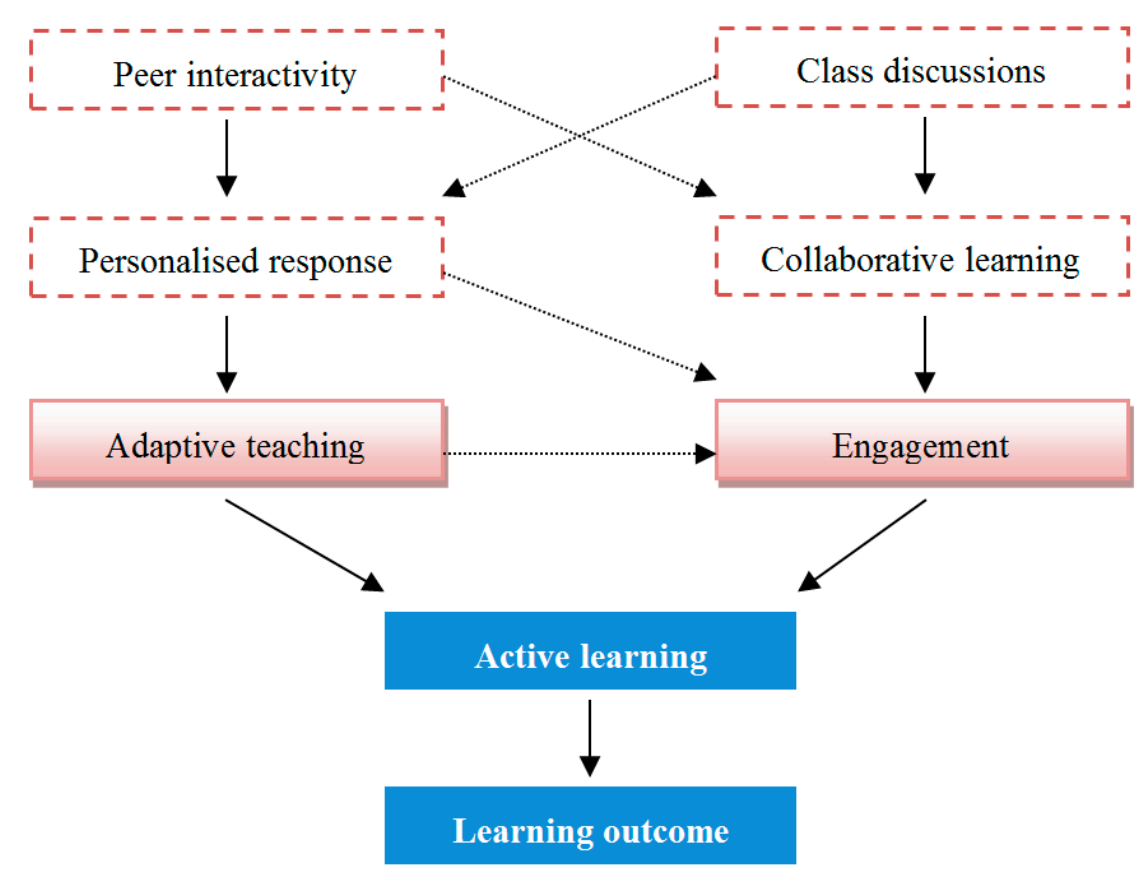

Figure 1. Learning concept framework using interactive technology with infotainment.

The analysis shows the flow of teaching tactics and pedagogies to enhance active learning and student learning outcome [59]. The use of clickers increases interactivity, adaptive teaching, and then engagement, stimulating students to participate in active learning for better learning outcomes. This pedagogical rationale underpins the implementation of interactive technology with infotainment in class.

The learning sequence in the railway engineering module can be designed as illustrated in Figure 2 [60-63]. As a result of a successful class in 2016, the development of learning resources to integrate interactive technology and infotainment was to foster individual responses and engagement 
in all students (in the United Kingdom, European Union, and internationally). The novel feature of clickers associated with infotainment questions was incorporated in various learning activities. The initial step was to identify audiences and to tailor teaching tactics and styles. For example, more than $70 \%$ of students were not from civil engineering fields, so further explanations of terminologies and concepts were a must. To add authenticity and engagement, small group discussions and feedback were also enacted together with individual responses and "fun-oriented" questions. The learning design has proven to be flexible and adaptive in that blended teaching tactics have been used in the class. The teaching materials and Panopto video recordings are also available on Canvas for students to review for exams at the end of the year.

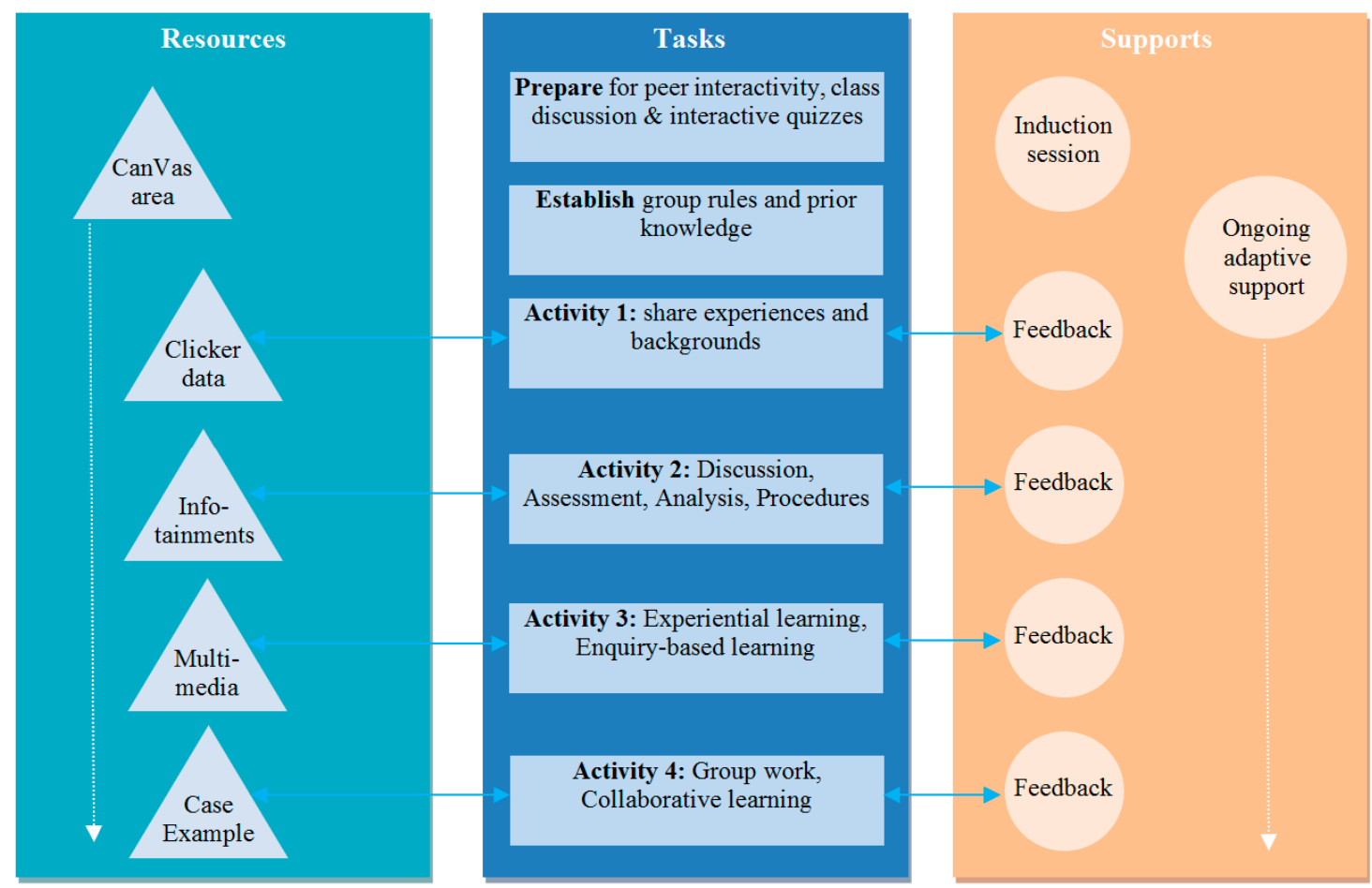

Figure 2. Learning design sequence using interactive technology with infotainment, adopted from McLinden and Hinton [60].

\section{Results and Discussion}

Participation data of both academic years 2016 and 2017 were gathered from the questionnaires. These data were used to determine student demography and perception. Attendance in 2017 was slightly higher than that in 2016. Note that student attendance does count toward the final mark. Table 2 shows the demographic comparison of student cohorts in both years. This confirms that rail is a male-dominated industry and the majority of students are international with some professional experience. The majority of the students (around 70\%) are of mature age (between 25 to 35 years old), which also implies that they are more responsible for their own learning and target career paths. As a result, class discussions should be made relevant and sensitive to various groups of students in order to draw on students' previous experiences and exposure for class discussions and interactions. The results in Table 2 show an interesting outcome that both 2016 and 2017 cohorts did not enjoy using online learning technology. They prefer face to face learning and interaction, which also results in human connection and networking. 
Table 2. Demographics of student backgrounds (all combined cohorts who took the class).

\begin{tabular}{ccc}
\hline Demography & $\begin{array}{c}\text { 2016 Cohort * } \\
\text { (Traditional Class Discussion) }\end{array}$ & $\begin{array}{c}\text { 2017 Cohort * } \\
\text { (Interactive Technology) }\end{array}$ \\
\hline Male & $60 \%$ & $78 \%$ \\
Female & $40 \%$ & $22 \%$ \\
Hative English speaker & $38 \%$ & $45 \%$ \\
Enjoy using technology & $56 \%$ & $58 \%$ \\
Total number of survey response & $38 \%$ & $28 \%$ \\
Total number of enrolment & 35 & 46 \\
\hline
\end{tabular}

* Note: these numbers were based on the actual students in the class. These students may or may not take the end-of-program exams for graduation as they may prolong their studies.

Note that the survey was planned using the university standard practice. The questionnaires were developed in consultation with the university's Higher Education Office to assure that the specific research objectives can be determined for educational improvement without jeopardizing students' data privacy. Based on the survey results, student perceptions of using class discussion and clickers are shown in Figure 3. The student surveys in 2016 and 2017 show that students enjoyed the interactive teaching class slightly more and felt they were significantly engaged in the class with the new interactive resource. The average scores are consistently higher for the 2017 student cohort who had used interactive technology (compared with those in 2016). This implies that a positive experience could be attained when using the interactive technologies. Considering the adaptive teaching approach, the students felt that the subject is less difficult and they needed lesser online support (such as simulation or video record). This insight can be derived from the apparent change in student perceptions. The survey data also implies that students perceive considerable value in interactive technology with infotainment, especially when the students can interact with smart phone devices. The score on the preference of using smart phones is higher than interacting via Canvas (an online class communication tool).

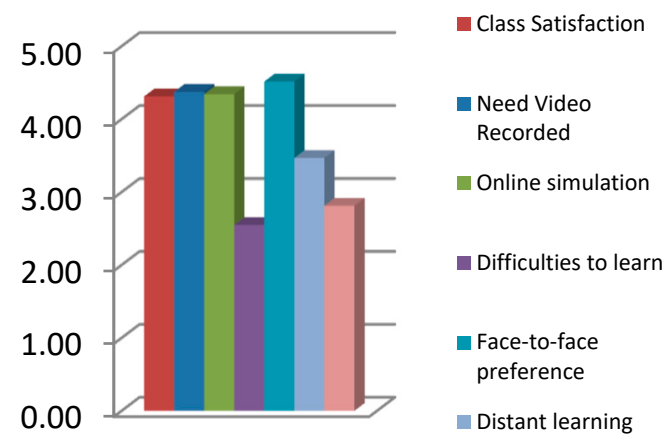

(a)

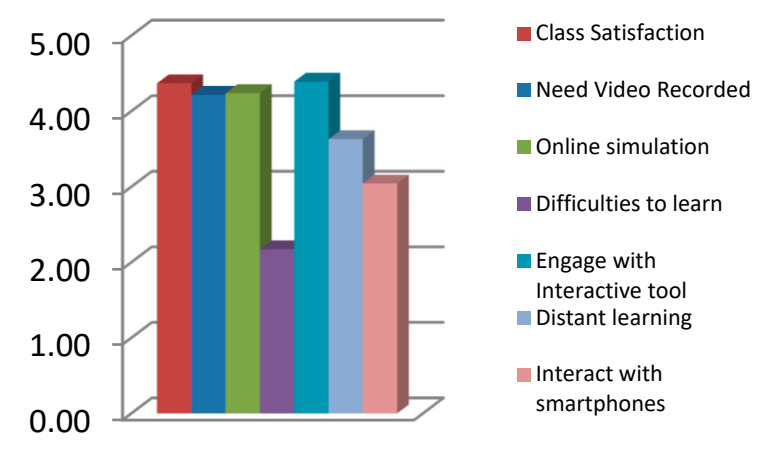

(b)

Figure 3. Student perceptions (a) average values in 2016 and (b) average values in 2017. Note that the mean standard deviation is about \pm 1.07 in 2016 and about \pm 0.92 in 2017 .

Despite the favorable outcomes, Table 3 displays some student comments from the 2017 cohort. The mixed comments from positive and negative responses can be observed. Based on the free comment feedback obtained from the survey, the adaptability, flexibility, and viability of using this interactive technology still largely depends on the students' backgrounds and their previous experience. These comments reflect the need to identify the audiences early on and to tune the teaching tactics to accommodate the learning styles preferred by different groups of students. For example, native English speaking students would enjoy more class discussions in combination with the interactive technology, since vocal discussions can be considered their strength. However, very positive comments 
were obtained frequently from students of various backgrounds. Based on students' verbal and written feedback, non-native English students tend to significantly complement the use of clickers for engagement and entertainment, since public speaking and discussion is one of their weaknesses or sources of discomfort. The lesson learnt from the use of interactive technology (or clickers) was that a teacher cannot overestimate the potential of technology without being responsive to the students and the cohort. Again they say, "one size does not fit all". The teaching process must be ready to be adaptively and optimally tailored to suit the combination of the class and each student's need.

Table 3. Selection of student comments from the 2017 cohort using clickers.

\begin{tabular}{l} 
Student Comments \\
\hline Investigate how people could be encouraged to interact verbally. \\
- Great effort, well done. \\
definitions of alignment and geometry-very confusing. \\
I would have liked to work through the work example with the class, i.e., for the lecturer to show us afterward. \\
Ensure video lecture is available online. \\
- I liked the interactive tool. I am a designer and it was good to hear it from an academic view. \\
- I prefer if concepts were detailed better in lectures. \\
- Use of technology was good. Kept me engaged.
\end{tabular}

At the end of the year 2016/2017, student learning outcomes could be measured by considering the score on the end-of-year oral examination of students (based on the curriculum of MSc Railway Risk and Safety Management). All students in the program must undergo the oral examination (which could permit the lecturer to assess the round understanding of the topic issue). This study has adopted the oral examination for the baseline, as other students in other program will be required to take the final exam combining various parts or sub-modules (e.g., train-track interaction, transit space, etc.) within the infrastructure exam. As such, the final exam results could not be used to distinguish the effectiveness of the teaching tactic in this paper. Therefore, only the oral examination has been chosen for further analysis. The oral examination was carried out by two faculty members by asking technical questions and listening to the student responses. A score for each student was awarded by each faculty member and then an average mark was used for the final outcome. Figure 4 illustrates the comparison of overall academic merit ranking. Note that A implies "excellent", with a mark over $70 \%$; B is "good", with a mark between $60 \%$ and $70 \%$; $\mathrm{C}$ is "fair", with a mark between $50 \%$ and $60 \%$; $\mathrm{D}$ is "poor", between $40 \%$ and $50 \%$; and $\mathrm{F}$ is a fail grade ( under $40 \%$ ). As discussed earlier in Section 4 , Figures 1 and 2 show the educational design of the classes in both years (2016 and 2017). The outcome in this study (as in Figure 4) clearly distinguishes the learning outcome of students from different teaching techniques.

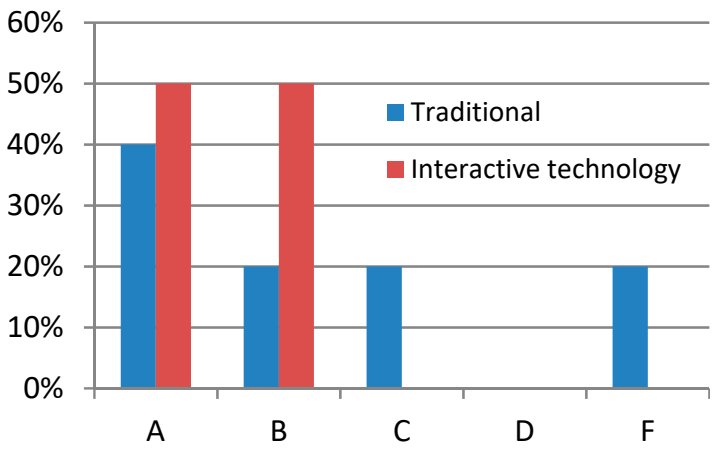

(a)

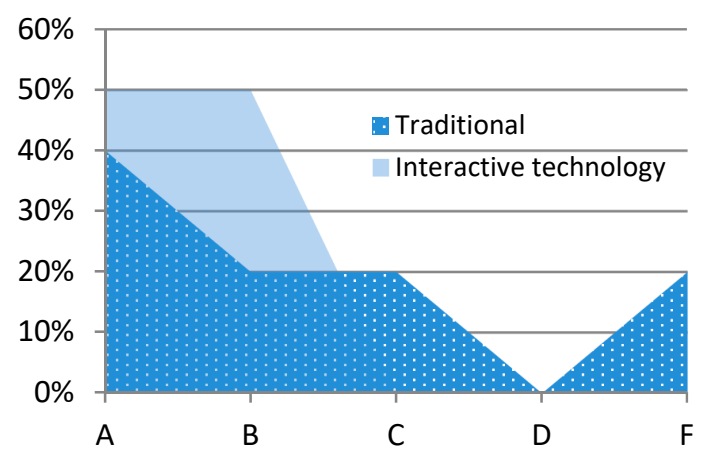

(b)

Figure 4. Comparison of student learning outcomes: (a) comparative bar chart of academic merit; and (b) area of influence on overall academic merit. 
Based on the number of candidates (11 May 2017), Figure 4 shows that students who used interactive technology tend to outperform those students using traditional teaching tools. All students $(100 \%)$ who used clickers could tackle the oral examination with a mark well above $60 \%$, whilst only $60 \%$ of the students who used the traditional class discussion approach could achieve a mark above $60 \%$ (B level). It is apparent that about $40 \%$ of students who did not use the interactive teaching approach performed poorly and up to $20 \%$ of them could also fail the oral exam. Based on this exam result, it shows that the interactive technology has a positive impact on the overall student attitudes and student engagement, resulting in higher learning performance. The next generation of students will rely on digital classrooms and the interactive teaching must be adapted to function with online technology in the future. Note that this study is based on the assumption that students do not suffer from poor English proficiency or any cultural barriers during the classes, survey examination, and other assessments. The cultural aspects are beyond the scope of this study.

\section{Conclusions}

An interactive technology (clickers) was used in conjunction with infotainment in a postgraduate railway engineering module in 2017. This development responds to many elements of the United Kingdom Professional Standards Framework in the Digital Age. Due to the virtue of interactive communication, the classroom is now expected to enable a combination of interaction-based learning technologies integrated with practical enquiry-based projects and case studies for improving employability skills. The application of clickers is aimed at improving student engagement, which could lead to intrinsic motivation and active learning, and to eventually improve the learning outcomes of the students. This paper shows that the use of clickers can prompt the lecturer to tailor the teaching styles and tactics to improve the understanding of the students. From this study, a number of conclusions can be identified:

- Blended infotainment and interactive technology can form an adaptive teaching pedagogy to increase student engagement in the railway geometry and alignment design class.

- The student surveys highlight the enjoyment, stimulation, and engagement of students in class, leading to improved learning performance.

- Students also perceive added value of interactive technology integrated with infotainment, renewing their learning participation.

- Despite the positive outcomes, the flexibility and viability of using this interactive technology still largely depends on the nature of the audiences.

It should be noted that this study was based on a limited number of sample data. It was also the first time the author had facilitated the class using clickers. On this ground, future work will include a more adaptive teaching style to enact active learning for all students and to further analyse the final exam marks of the students. In addition, another type of interactive technology, such as augmented reality, will be considered to improve the student engagement in class.

Author Contributions: Conceptualization, S.K.; methodology, S.K.; software, S.K.; validation, S.K.; formal analysis, S.K.; investigation, S.K.; resources, S.K.; data curation, S.K.; writing一original draft preparation, S.K.; writing-review and editing, S.K.; visualization, S.K.; project administration, S.K.; funding acquisition, S.K.

Funding: This project has received funding from the European Union's Horizon 2020 research and innovation programme under the Marie Skłodowska-Curie grant agreement No 691135 “RISEN: Rail Infrastructure Systems Engineering Network". The APC was funded by The University of Birmingham Library's Open Access Fund.

Acknowledgments: S.K. wishes to thank the Australian Academy of Science and the Japan Society for the Promotion of Sciences for his Invitation Research Fellowship (Long-term) at the Railway Technical Research Institute and The University of Tokyo, Japan. The authors wish to gratefully acknowledge the financial support from the European Commission for H2020-MSCA-RISE Project No. 691135 “RISEN: Rail Infrastructure Systems Engineering Network", which enables a global research network that tackles the grand challenges [64] in railway infrastructure resilience and advanced sensing in extreme events (www.risen2rail.eu). The technical review and constructive comments by Danielle Hinton and Marios Hadjianastasis are gratefully acknowledged.

Conflicts of Interest: The authors declare no conflict of interest. 
Appendix A

Sample of teaching slides

\section{Superelevation}

Example:

Vehicle speed $=80 \mathrm{kph}$

Curve radius $=500 \mathrm{~m}$

Balanced superelevation $=151 \mathrm{~mm}$

At balanced superelevation, the vertical loads on the outer (high) and inner (low) rails should be equal.

If balanced superelevation is less than $20 \mathrm{~mm}$, or if speeds are less than $\mathbf{4 0} \mathrm{kph}$, track superelevation is generally disregarded.

Figure A1. Lecture Slide in 2016 (Traditional Class Discussion).

Example (2 mins):

Vehicle speed $=80 \mathrm{~km} / \mathrm{h}$

Curve radius $=500 \mathrm{~m}$

Standard gauge $\mathrm{g}=1.435 \mathrm{~m}$

Rail cant 1:20

Rail head width $70 \mathrm{~mm}$.

What is balanced super?
A. $140 \mathrm{~mm}$
B. $150 \mathrm{~mm}$
C. $160 \mathrm{~mm}$
D. I don't know.

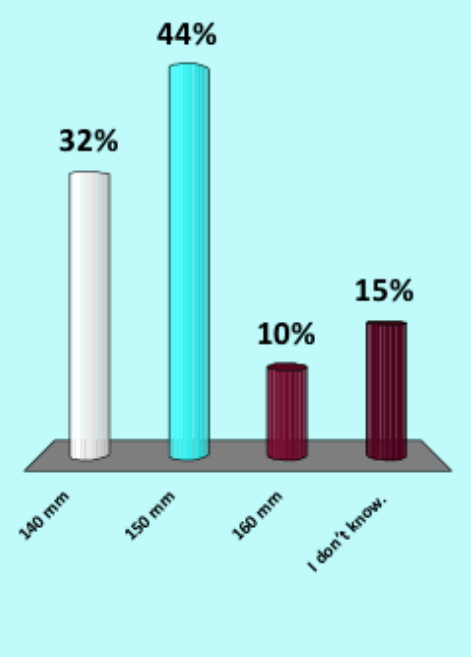

Note: At balanced superelevation, the vertical loads on the outer (high) and inner (low) rails should be equal. If balanced superelevation is less than $20 \mathrm{~mm}$, or if speeds are less than $40 \mathrm{kph}$, track superelevation is generally disregarded.

Figure A2. Interactive Lecture Slide in 2017 (Interactive Technology with Infotainment). 


\section{Appendix B}

Case Study for Class Discussion

Infrastructure Module

Rail Geometry and Alignment Design

Group Discussion - Work in Group of 3 students

(10 mins $=8$ mins discussion +2 mins reporting)

A train derailed at a yard in Manchester. The derailment occurred in a hot summer while the empty freight train run at the speed of $20 \mathrm{~km} / \mathrm{h}$. The yard manager investigated the scene and reported that a freight train wheel climbed over a shallow transition (500m radius) of the open plain track, commencing from the high rail (outer rail). The yard manager complained that 'this derailment was because of wrong track geometry design'. This rumour was somehow leaked to a daily morning herald.

You are a stellar Birmingham alumnus and have recently been appointed as the CEO of the railway company. A news reporter from Chanel $\mathbf{X X X}$ is live on a teleconference interviewing you about this incident.

The reporter asked you "Can you confirm that this derailment was due to wrong curve design?"

What would be your reply?

Yes or No?

Based on your previous study back in your stellar year in Birmingham, you know that the risk of wheel climbing derailment depends on critical lateral and vertical force ratio $(L / M)$ :

$\frac{L}{V}=\frac{\tan \delta-\mu}{1+\mu \tan \delta}$

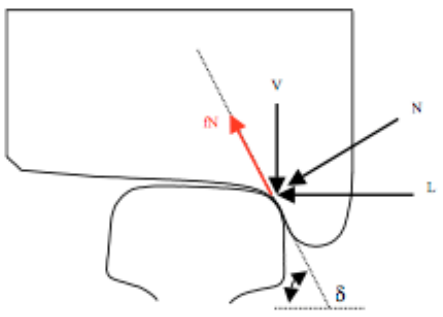

Figure A3. Case discussion on the potential causes of a train derailment

\section{Appendix C}

A sample of questionnaires to understand student perception (2017) 


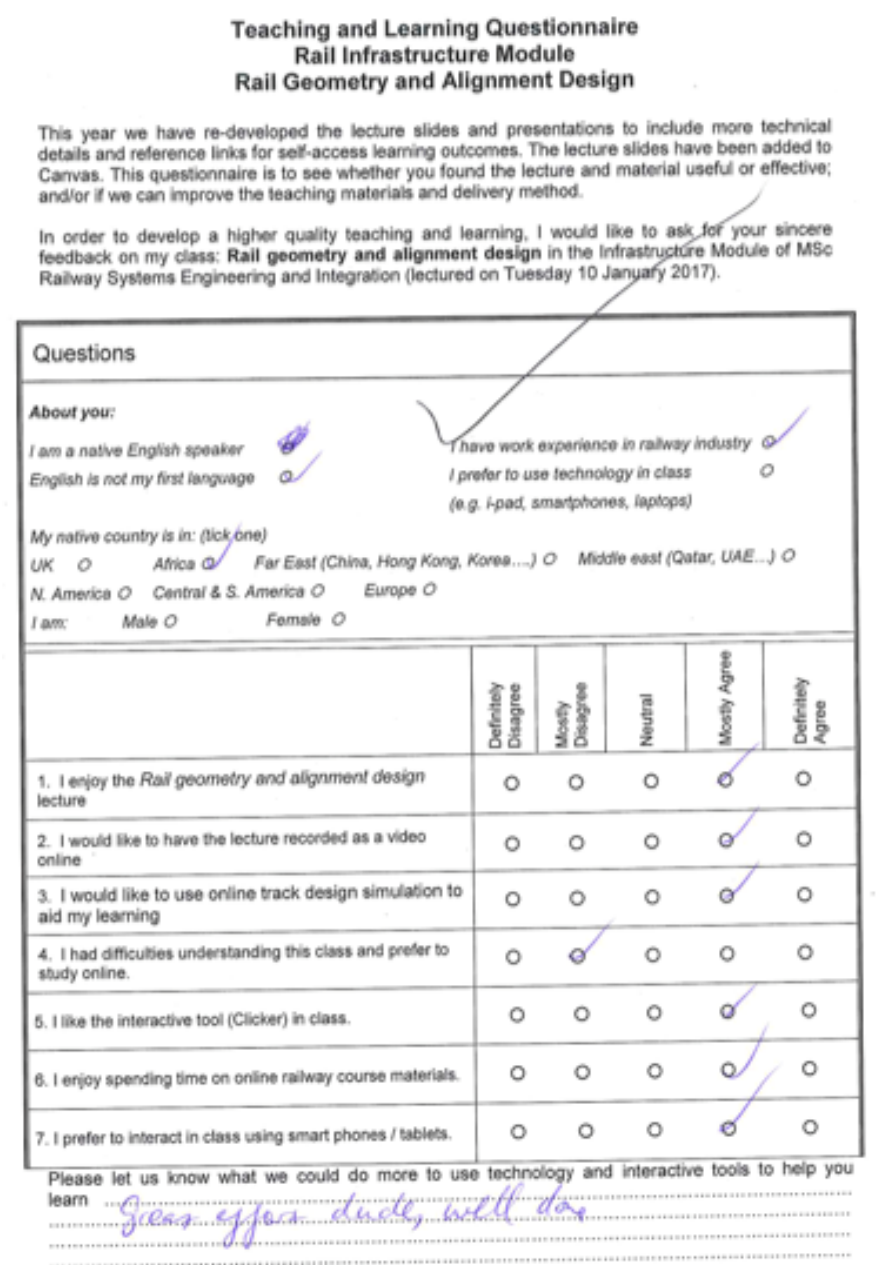

Figure A4. Example of student feedback

\section{References}

1. Armour, K. Message to All Staff from Pro Vice Chancellor (Education), E-mail Communication to All Staff on 13 September 2016; The University of Birmingham: Birmingham, UK, 2016.

2. Kaewunruen, S. Underpinning systems thinking in railway engineering education. Australas. J. Eng. Educ. 2018. [CrossRef]

3. UKPSF (UK Professional Standards Framework). The UK Professional Standards Framework for Teaching and Supporting Learning in Higher Education; The Higher Education Academy, Guild HE, Universities UK: London, UK, 2011.

4. Guthrie, R.; Carlin, A. Waking the Dead: Using interactive technology to engage passive listeners in the classroom. In Proceedings of the Tenth Americas Conference on Information Systems, New York, NY, USA, 6-8 August 2004; pp. 2952-2959.

5. Ribeiro, L.R.C.; Mizukami, M.D.G.N. Problem-based learning: A student evaluation of an implementation in postgraduate engineering education. Eur. J. Eng. Educ. 2005, 30, 137-149. [CrossRef]

6. Kirkwood, A. E-learning: You don't always get what you hope for. Technol. Pedagog. Educ. 2009, 18, $107-121$. [CrossRef]

7. Blasco-Arcas, L.; Buil, I.; Hernández-Ortega, B.; Javier Sese, F. Using clickers in class. The role of interactivity, active collaborative learning and engagement in learning performance. Comput. Educ. 2013, 62, 102-110. [CrossRef]

8. Caldwell, J.E. Clickers in the Large Classroom: Current Research and Best-Practice Tips. CBE Life Sci. Educ. 2007, 6, 9-20. [CrossRef] [PubMed]

9. Schmidt, B. Teaching engineering dynamics by use of peer instruction supported by an audience response system. Eur. J. Eng. Educ. 2011, 36, 413-423. [CrossRef] 
10. Han, J.H.; Finkelstein, A. Understanding the effects of professors' pedagogical development with Clicker Assessment and Feedback technologies and the impact on students' engagement and learning in higher education. Comput. Educ. 2013, 65, 64-76. [CrossRef]

11. Brady, M.; Seli, H.; Rosenthal, J. “Clickers” and metacognition: A quasi-experimental comparative study about metacognitive self-regulation and use of electronic feedback devices. Comput. Educ. 2013, 65, 56-63. [CrossRef]

12. Crossgrove, K.; Curran, K.L. Using Clickers in Nonmajors- and Majors-Level Biology Courses: Student Opinion, Learning, and Long-Term Retention of Course Material. CBE Life Sci. Educ. 2008, 7, $146-154$. [CrossRef]

13. Kennewell, S.; Tanner, H.; Jones, S.; Beauchamp, G. Analysing the use of interactive technology to implement interactive teaching. J. Comput. Assist. Learn. 2007, 24, 61-73. [CrossRef]

14. Bojinova, E.; Oigara, J. Teaching and learning with clickers in higher education. Int. J. Teach. Learn. High. Educ. 2013, 25, 154-165.

15. Beatty, I.D.; Gerace, W.J.; Leonard, W.J.; Dufresne, R.J. Designing effective questions for classroom response teaching. Am. J. Phys. 2006, 74, 31-39. [CrossRef]

16. Martyn, M. Clickers in the classroom: An active learning approach. In Proceedings of the Annual Conference EDUCAUSE, Philadelphia, PA, USA, 31 October-3 November 2007.

17. Bruff, D. Teaching with Classroom Response Systems: Creating Active Learning Environments; Jossey-Bass: San Francisco, CA, USA, 2009.

18. Mazur, E. Peer Instruction: A User's Manual; Pearson: New York, NY, USA, 1997.

19. McKnight, K.; O’Malley, K.; Ruzic, R.; Horsley, M.K.; Franey, J.J.; Bassett, K. Teaching in a digital age: How educators use technology to improve student learning. J. Res. Technol. Educ. 2016, 48, 194-211. [CrossRef]

20. Johnson, D.W.; Johnson, R.T.; Smith, K.A. Active Learning: Cooperation in the College Classroom; Interaction Book Company: Edina, MN, USA, 1998.

21. Jenkin, M. Learning through Play: Pedagogy, Challenges and Ideas-Live Chat, The Guardian. 2013. Available online: https://www.theguardian.com/teacher-network/teacher-blog/2013/feb/15/learning-playimaginative-inquiry-teaching-schools-live-chat (accessed on 1 January 2019).

22. Laxman, K. A study on the adoption of clickers in higher education. Australas. J. Educ. Technol. 2011, 27, 1291-1303. [CrossRef]

23. O'Flaherty, J.; Phillips, C. The use of flipped classrooms in higher education: A scoping review. Internet High. Educ. 2015, 25, 85-95. [CrossRef]

24. Bernard, R.M.; Borokhovskil, E.; Schmid, R.F.; Tamim, R.M.; Abrami, P.C. A meta-analysis of blended learning and technology use in higher education: From the general to the applied. J. Comput. High. Educ. 2014, 26, 87-122. [CrossRef]

25. Elliott, C. Using a Personal Response System in Economics Teaching. Int. Rev. Econ. Educ. 2003, 1, 80-86. [CrossRef]

26. Hannay, M.; Fretwell, C. The higher education workplace: Meeting the needs of multiple generations. Res. High. Educ. J. 2011, 10, 1-12.

27. Junco, R.; Heibergert, G.; Loken, E. The effect of Twitter on college student engagement and grades. J. Comput. Assist. Learn. 2011, 27, 119-132. [CrossRef]

28. Ferreri, S.P.; O'Connor, S.K. Redesign of a large lecture course into a small-group learning course. Am. J. Pharm. Educ. 2013, 77, 13. [CrossRef]

29. McKinney, K.; Heyl, B. (Eds.) Sociology through Active Learning; SAGE/Pine Forge Press: Thousand Oaks, CA, USA, 2008.

30. Kassens-Noor, E. Twitter as a teaching practice to enhance active and informal learning in higher education: The case of sustainable tweets. Act. Learn. High. Educ. 2012, 13, 9-21. [CrossRef]

31. Machemer, P.L.; Crawford, P. Student perceptions of active learning in a large cross-disciplinary classroom. Act. Learn. High. Educ. 2007, 8, 9-30. [CrossRef]

32. Cavanagh, M. Students' experiences of active engagement through cooperative learning activities in lectures. Act. Learn. High. Educ. 2011, 12, 23-33. [CrossRef]

33. Lean, J.; Moizer, J.; Towler, M.; Abbey, C. Simulations and games: Use and barriers in higher education. Act. Learn. High. Educ. 2006, 7, 227-242. [CrossRef] 
34. Bingimals, K.A. Barriers to the successful integration of ICT in teaching and learning environ-ments: A review of the literature. Eurasia J. Math. Sci. Technol. Educ. 2009, 5, 235-245. [CrossRef]

35. Davis, M. Barriers to Reflective Practice: The Changing Nature of Higher Education. Act. Learn. High. Educ. 2003, 4, 243-255. [CrossRef]

36. Walker, S.E. Active learning strategies to promote critical thinking. J. Athl. Train. 2003, 38, $263-267$.

37. Yazedjian, A.; Boyle Kolkhorst, B. Implementing Small-Group Activities in Large Lecture Classes. Coll. Teach. 2007, 55, 164-169. [CrossRef]

38. Chan, T.F.I.; Borja, M.; Welch, B.; Batiuk, M.E. Predicting the probability for faculty adopting an audience response system in higher education. J. Inf. Technol. Educ. Res. 2016, 15, 395-407.

39. Gould, S.M. Potential use of classroom response systems (CRS, Clickers) in foods, nutrition, and dietetics higher education. J. Nutr. Educ. Behav. 2016, 48, 669-674. [CrossRef]

40. Katz, L.; Hallam, M.C.; Duvall, M.M.; Polsky, Z. Considerations for using personal Wi-Fi enabled devices as "clickers" in a large university class. Act. Learn. High. Educ. 2017, 18, 25-35. [CrossRef]

41. Bryson, C. Engagement through partnership: Students as partners in learning and teaching in higher education. Int. J. Acad. Dev. 2016, 21, 84-86. [CrossRef]

42. Christie, M.; de Graaff, E. The philosophical and pedagogical underpinnings of active learning in engineering education. Eur. J. Eng. Educ. 2017, 42, 5-16. [CrossRef]

43. Chiu, P.H.P. A technology-enriched active learning space for a new gateway education programme in Hong Kong: A platform for nurturing student innovations. J. Learn. Spaces 2016, 5, 52-60.

44. Dreher, R.; Simpson, C.; Sørensen, O.J.; Turcan, R.V. (Eds.) When Students Take the Lead: Enhancing Quality and Relevance of Higher Education through Innovation in Student-Centred Problem-Based Active Learning. In Proceedings of the PBLMD International Conference, Chisinau, Moldova, 27-28 October 2016.

45. Englund, C.; Olofsson, A.D.; Price, L. Teaching with technology in higher education: Understanding conceptual change and development in practice. High. Educ. Res. Dev. 2017, 36, 73-87. [CrossRef]

46. Hassan, N.F.; Saifullizam, P. A survey of technology enabled active learning in teaching and learning practices to enhance the quality of engineering students. Adv. Sci. Lett. 2017, 23, 1104-1108. [CrossRef]

47. Jones, C.; Shao, B. The Net Generation and Digital Natives, Implications for Higher Education; A Literature Review; Higher Education Academy: Milton Keynes, UK, 2011; p. 56.

48. Hunsu, N.J.; Adesope, O.; Bayly, D.J. A meta-analysis of the effects of audience response systems (clicker-based technologies) on cognition and affect. Comput. Educ. 2016, 94, 102-119. [CrossRef]

49. Shapiro, A.M.; Sims-Knight, J.; O’Rielly, G.V.; Capaldo, P.; Pedlow, T.; Gordon, L.; Monteiro, K. Clickers can promote fact retention but impede conceptual understanding: The effect of the interaction between clicker use and pedagogy on learning. Comput. Educ. 2017, 111, 44-59. [CrossRef]

50. Hassanin, H.; Essa, K.; El-sayed, M.A.; Attallah, M.M. Enhancement of student learning and feedback of large group engineering lectures using audience response systems. J. Mater. Educ. 2016, 38, 175-190.

51. Selvi, R.T.; Chandramohan, G. Peer Assessment of Oral Presentation: An Investigative Study of Using Clickers in First-Year Civil Engineering Class of a Reputed Engineering Institution. In Proceedings of the 2016 IEEE Eighth International Conference on Technology for Education (T4E), Mumbai, India, 2-4 December 2016; pp. 132-135.

52. Khan, P.; O'Rourke, K. Guide to Curriculum Design: Enquiry-Based Learning; Higher Education Academy: Manchester, UK, 2004.

53. Kolb, D.A. Experiential Learning: Experience as the Source of Learning and Development; Pearson Education: Englewood Cliffs, NJ, USA, 2015.

54. Eyler, J. The power of experiential education. Lib. Educ. 2009, 95, 24-31.

55. Kaewunruen, S. Final Report for Effective Academic Practice in Higher Education, PGCert in Academic Practice; The University of Birmingham: Birmingham, UK, 2016; p. 24.

56. Conner, H.; Dench, S.; Bates, P. An Assessment of Skill Needs in Engineering; Department for Education and Employment Publications: Nottingham, UK, 2000.

57. Zaharim, A.; Md Yusoff, Y.; Omar, M.Z.; Mohamed, A.; Muhamad, N. Engineering Employability Skills Required by Employers in Asia. In Proceedings of the 6th WSEAS International Conference on Engineering Education, Rodos Island, Greece, 22-24 July 2009. 
58. Hoekstra, A.; Mollborn, S. How clicker use facilitates existing pedagogical practices in higher education: Data from interdisciplinary research on student response systems. Learn. Media Technol. 2012, 37, 303-320. [CrossRef]

59. Camacho-Miñano, M.D.; del Campo, C. Useful interactive teaching tool for learning: Clickers in higher education. Interact. Learn. Environ. 2016, 24, 706-723. [CrossRef]

60. McLinden, M.; Hinton, D. EBL for teachers of the visually impaired, Talking about Learning E Teaching Case Study 008; University of Birmingham: Birmingham, UK, 2010.

61. Vuopala, E.; Hyvonen, P.; Jarvela, S. Interaction forms in successful collaborative learning in virtual learning environments. Act. Learn. High. Educ. 2016, 17, 25-38. [CrossRef]

62. Kaewunruen, S.; Tang, T. Idealisations of Dynamic Modelling for Railway Ballast in Flood Conditions. Appl. Sci. 2019, 9, 1785. [CrossRef]

63. Setsobhonkul, S.; Kaewunruen, S.; Sussman, J.M. Lifecycle Assessments of Railway Bridge Transitions Exposed to Extreme Climate Events. Front. Built Environ. 2017, 3, 35. [CrossRef]

64. Kaewunruen, S.; Sussman, J.M.; Matsumoto, A. Grand Challenges in Transportation and Transit Systems. Front. Built Environ. 2016, 2, 4. [CrossRef]

(C) 2019 by the author. Licensee MDPI, Basel, Switzerland. This article is an open access article distributed under the terms and conditions of the Creative Commons Attribution (CC BY) license (http://creativecommons.org/licenses/by/4.0/). 